\title{
A COMPARATIVE STUDY ON TWO FORMS OF CANDIDA TROPICALIS (CAST.) BERKHOUT
}

\author{
TAKASHI NAKASE, ${ }^{1}$ YOSHIMURA FUKAZAWA, ${ }^{2}$ \\ AND TAKESHI TSUCHIYA \\ Department of Bacteriology, School of Medicine, \\ Juntendo University, Tokyo 113, Japan
}

(Received June 10, 1972)

\begin{abstract}
Taxonomic studies on 32 strains of Candida tropicalis and its allies revealed that they could be divided into two forms. C. tropicalis form I (24 strains) had a GC content of 34.1-34.9\%, assimilated soluble starch, had an antigenic structure of $1,2,3,4,5,6$, and formed wrinkled colonies with hair when they aged. C. tropicalis form II (8 strains) had a GC content of $36.3-36.8 \%$, did not assimilate soluble starch, had an antigenic structure of $1,2,3,4$, (5), (6), and formed smooth colonies without hair when they aged. These two forms are also differentiated by the proton magnetic resonance spectra of alkali-extracted mannans. Since taxonomic characteristics of strains of form I are identical with those of the standard description of C. tropicalis, the strains of form II should be represented as a new species. The name Candida subtropicalis is proposed for the strain of form II and the description of this species is given.
\end{abstract}

It is well known that the yeast Candida tropicalis (CAST.) BERKHOUT rapidly assimilates soluble starch as a sole source of carbon, and strains which lack this ability have not been recorded in the literatures (1-3). In the past few years, however, several strains of yeast which resemble $C$. tropicalis but do not assimilate this carbon compound have often been isolated from natural sources. The present authors provisionally dealt with these strains as $C$. tropicalis form II and with those of typical C. tropicalis, which assimilate soluble starch, as C. tropicalis form I (4). After a precise comparative study on these two forms, it was clarified that they were closely related to each other but could be clearly differentiated on the basis of the GC content in DNA and serological characteristics, in addition to the taxonomic criteria commonly employed.

1 Present Address: Central Research Laboratories, Ajinomoto Co., Inc., Kawasaki 210, Japan.

2 Present Address: Meiji Pharmaceutical College, Setagayaku, Tokyo 154, Japan. 


\section{MATERIALS AND METHODS}

Microorganisms. Thirty-two strains of Candida tropicalis and its allies were employed. Source of strains is listed in Table 1. Candida albicans J1501, C. stellatoidea J-1016, C. guilliermondii J-1023, C. parapsilosis (C. parakrusei) J-1015, C. krusei J-1005, and Torulopsis glabrata J-4002 were also used in the serological investigation.

Taxonomic characteristics. Taxonomic characteristics were investigated mainly by the methods of WickerhaM (5), and of LODDER and KREGERVAN RIJ ( 6 ). Macromorphology, vitamin requirement and maximum growth temperature were determined by the procedures previously reported $(7,8)$.

Determination of DNA base composition. DNAs were isolated and purified by the method previously reported (9). The DNA base composition was calculated from the thermal denaturation temperature $(\mathrm{Tm})$ using the formula of MARMUR and DOTY (10). Tm was measured by the apparatus described by YAMADA and KOMAGATA ( 11 ).

Extraction and purification of polysaccharide. The yeast cells grown for $48 \mathrm{hr}$ on Sabouraud's agar medium were harvested and washed 3 times with distilled water and heated at $100^{\circ}$ for $2 \mathrm{hr}$. After centrifugation, the cells were suspended in 5 volumes of $2 \%$ aqueous potassium hydrochloride solution and extracted for $2 \mathrm{hr}$ at $100^{\circ}$. The succeeding procedures for extraction and purification of polysaccharide followed the methods reported by GORIN and SPENCER ( 12 ).

Antigenic analysis. The methods for the preparation of antisera, the slide agglutination test, and the absorption test of agglutinins were similar to those described previously (13).

Gel diffusion precipitation method. Precipitation reactions were performed by the gel diffusion method using $0.85 \%$ of Noble agar (Difco) in borate buffer, $\mathrm{pH} 8.4$ (14). A $0.1 \%$ solution of purified polysaccharide was used for antigen in the outer wells and undiluted antiserum was placed in the central well.

Determination of proton magnetic resonance spectrum of polysaccharide. The proton magnetic resonance (PMR) spectrum was determined with 20\% solution of polysaccharide in $\mathrm{D}_{2} \mathrm{O}$ at $70^{\circ}$ using a Hitachi $60-\mathrm{MHz}$ nuclear magnetic resonance spectrometer in which tetramethylsilane was used as external standard.

\section{RESULTS}

\section{Taxonomic characteristics}

As shown in Tables 2 and 3, two forms of $C$. tropicalis closely resembled each other in taxonomic criteria commonly employed. A few differences were found in the following characteristics: Strains assigned to $C$. tropicalis form I usually formed wrinkled colonies with characteristic hair when they aged, 
Table 1. Strains employed.

\begin{tabular}{|c|c|c|}
\hline Species & Strain & Source \\
\hline C. tropicalis form I & AJ 4468 & IFO 0006 \\
\hline "I & AJ 4469 & IFO 0589 \\
\hline$\prime \prime$ & AJ 4470 & RIFY WF-191 \\
\hline$\prime \prime$ & AJ 4471 & Spinach \\
\hline$\prime \prime$ & AJ 4472 & "Moyashi" (Soybean sprouts) \\
\hline$\prime \prime$ & AJ 4473 & 11 \\
\hline$\prime \prime$ & AJ 4474 & $\prime \prime$ \\
\hline$\prime \prime$ & AJ 4475 & " \\
\hline$\prime \prime$ & AJ 4479 & No. 131 (K. Yamada) \\
\hline$\prime \prime$ & AJ 4486 & $a$ \\
\hline "l & AJ 4487 & $a$ \\
\hline "1 & AJ 4488 & $b$ \\
\hline$\prime \prime$ & AJ 4489 & $b$ \\
\hline$\prime \prime$ & AJ 4490 & $b$ \\
\hline$\prime \prime$ & AJ 4491 & $b$ \\
\hline "l & AJ 4492 & $c$ \\
\hline$\prime \prime$ & AJ 4493 & $b$ \\
\hline$\prime \prime$ & AJ 4494 & $b$ \\
\hline "I & AJ 4495 & $b$ \\
\hline$\prime \prime$ & AJ 4496 & $b$ \\
\hline$\prime \prime$ & AJ 4766 & C. benhamii $61 / 477$ IV (E. K. Novák) \\
\hline "l & AJ 4767 & C. benhamii $61 / 477$ IVa $(\quad \| \quad)$ \\
\hline "l & AJ 4780 & $b$ \\
\hline 11 & $\mathrm{~J}-1017$ & JFO 1016 \\
\hline C. tropicalis form II & AJ 4476 & Air, YO-146 (19) \\
\hline " & AJ 4477 & Air, YO-147 (19) \\
\hline "1 & AJ 4478 & Air, YO-148 (19) \\
\hline "1 & AJ 4480 & Soil, No. 315 (K. Yamada) \\
\hline " & AJ 4497 & Soil (R. Uchio) \\
\hline$\prime \prime$ & AJ 5095 & KY42-11 (K. Yamada) \\
\hline "l & AJ 4928 & N7Y1 $(\| \quad)$ \\
\hline " & AJ 5189 & HY4217 ( $" \prime) ~)$ \\
\hline
\end{tabular}

$a$ : Isolated from adhesives in a seasoning manufacturing plant.

$b$ : Isolated in a soybean protein factory.

$c$ : Isolated in a monosodium glutamate manufacturing plant. 
Table 2. Characteristics of two forms of Candida tropicalis (1).

\begin{tabular}{|c|c|c|c|c|c|c|c|c|c|c|}
\hline \multirow[b]{2}{*}{$\begin{array}{l}\text { Form of } \\
\text { C. tropicalis }\end{array}$} & \multirow[b]{2}{*}{$\begin{array}{c}\text { Appearance } \\
\text { of aged } \\
\text { colonies }\end{array}$} & \multirow[b]{2}{*}{$\begin{array}{l}\text { Maximum } \\
\text { growth } \\
\text { temperature } \\
\left({ }^{\circ} \mathrm{C}\right)\end{array}$} & \multirow[b]{2}{*}{$\begin{array}{l}\text { Vitamin } \\
\text { required }\end{array}$} & \multicolumn{7}{|c|}{ Fermentation } \\
\hline & & & & $\begin{array}{l}0 \\
0 \\
0 \\
0 \\
\vdots \\
0 \\
\vdots \\
\dot{0}\end{array}$ & $\begin{array}{l}0 \\
0 \\
0 \\
0 \\
0 \\
\frac{\pi}{\pi} \\
0 \\
\vdots \\
0\end{array}$ & 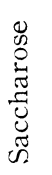 & 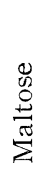 & 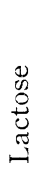 & 总 & 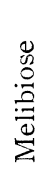 \\
\hline I & $\begin{array}{l}\text { Wrinkled } \\
\text { surface } \\
\text { with hair }\end{array}$ & $41-45$ & Biotin & + & + & + & + & - & - & - \\
\hline II & $\begin{array}{l}\text { Smooth or } \\
\text { wrinkled } \\
\text { surface } \\
\text { without } \\
\text { hair }\end{array}$ & $40-41$ & Biotin & + & + & + & + & - & - & - \\
\hline
\end{tabular}

had a maximum growth temperature of $41-45^{\circ}$, usually $43-45^{\circ}$, and assimilated soluble starch. C. tropicalis form II usually formed smooth colonies when they aged, had a maximum growth temperature of $40-41^{\circ}$, and did not assimilate soluble starch.

\section{DNA base composition}

Base composition of DNA (GC content) of representative strains of $C$. tropicalis form I and form II is shown in Table 4. All the DNA preparations obtained gave monophasic melting curves in denaturation experiment of DNA, and were assumed to be free from satellite components of DNA. Form I and form II of C. tropicalis showed GC values of 34.1-34.9\% (mean value, 34.5\%) and $36.3-36.8 \%$ (mean value, $36.6 \%$ ), respectively, and the difference between these two forms was $2.1 \%$.

\section{Serological analyses}

Reciprocal agglutinin absorption experiments were carried out among antisera for and heated cells of several strains of two forms of $C$. tropicalis (Table 5). Agglutinin reacting only with C. tropicalis J-1017 (form I) remained in the antiserum for C. tropicalis J-1017 absorbed with cells of $C$. tropicalis $\mathrm{AJ} 4468$ (form I), and also agglutinins reacting with both of $C$. tropicalis J1017 and AJ 4468 were demonstrated in the antiserum for C. tropicalis J-1017 absorbed with $C$. tropicalis AJ 4476 (form II). Antiserum for C. tropicalis AJ 4476 absorbed with strains of $C$. tropicalis form I or II did not agglutinate the cells of any form of $C$. tropicalis. These results indicate that the antiserum for C. tropicalis form II did not contain additional antigen for C. tropicalis form I, and that a slight antigenic difference also existed within strains of $C$. tropicalis form I.

Further reciprocal agglutinin absorption experiments were performed 
Table 3. Characteristics of two forms of Candida tropicalis (2). Assimilation of carbon compounds.

\begin{tabular}{|c|c|c|}
\hline Carbon compound & C. tropicalis form I & C. tropicalis form II \\
\hline D-Glucose & + & + \\
\hline D-Galactose & + & + \\
\hline Saccharose & + & + \\
\hline Maltose & + & + \\
\hline Lactose & - & - \\
\hline L-Sorbose & + or $\mathrm{L}$ & + or $\mathrm{L}$ \\
\hline Cellobiose & + or $\mathrm{L}$ & $\mathrm{V}$ \\
\hline Trehalose & + & + \\
\hline Melibiose & - & - \\
\hline Raffinose & - & - \\
\hline Melezitose & + & + \\
\hline Inulin & - & - \\
\hline Soluble starch & + & - \\
\hline D-Xylose & + & + \\
\hline L-Arabinose & $\mathrm{V}$ & - \\
\hline D-Arabinose & - & - \\
\hline D-Ribose & $\mathrm{V}$ & $\mathrm{V}$ \\
\hline L-Rhamnose & - & - \\
\hline Ethanol & + & + \\
\hline Glycerol & $\mathrm{V}$ & + or $\mathrm{L}$ \\
\hline Erythritol & - & - \\
\hline Adonitol & + & + \\
\hline Dulcitol & - & - \\
\hline D-Mannitol & + & + \\
\hline D-Sorbitol & + & + \\
\hline$\alpha$-Methyl-D-glucoside & + & + \\
\hline Salicin & + or $\mathrm{L}$ & $\mathrm{V}$ \\
\hline $\mathrm{K}$ gluconate & + & $\mathrm{L}$ \\
\hline Ca 2-ketogluconate & + & + \\
\hline DL-Lactic acid & + or $\mathrm{W}$ & $\mathrm{V}$ \\
\hline Succinic acid & + or $\mathrm{W}$ & + \\
\hline Citric acid & + or $\mathrm{W}$ & + or $\mathrm{L}$ \\
\hline Inositol & - & - \\
\hline
\end{tabular}

V: Variable, L: Latent, W : Weak. 
Table 4. DNA base composition of some strains of Candida tropicalis form I and II.

\begin{tabular}{c|c|c|c|c}
\hline Species & Strain & Tm $\left({ }^{\circ} \mathrm{C}\right)$ & $\begin{array}{l}\text { GC content in } \\
\text { DNA (mol. \%) }\end{array}$ & Reference \\
\hline C. tropicalis form I & AJ 4468 & 83.4 & 34.4 & 18 \\
$\prime \prime$ & AJ 4469 & 83.5 & 34.6 & 18 \\
$\prime \prime$ & AJ 4470 & 83.5 & 34.6 & \\
$\prime \prime$ & AJ 4471 & 83.3 & 34.1 & \\
$\prime \prime$ & AJ 4479 & 83.6 & 34.9 & \\
$\prime \prime$ & AJ 4488 & 83.4 & 34.4 & \\
$\prime \prime$ & AJ 4766 & 83.3 & 34.1 & \\
C. tropicalis form II & J-1017 & 83.3 & 34.1 & \\
$\prime \prime$ & AJ 4476 & 84.3 & 36.6 & \\
$\prime \prime$ & AJ 4478 & 84.4 & 36.8 & \\
\hline
\end{tabular}

Table 5. Reciprocal absorption experiments among strains of two forms of Candida tropicalis.

\begin{tabular}{|c|c|c|c|c|c|c|c|c|c|c|}
\hline Antisera for & Absorbed with & 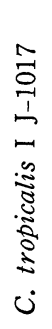 & 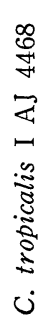 & 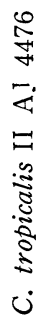 & 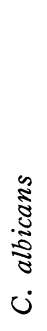 & 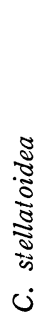 & 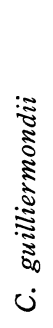 & 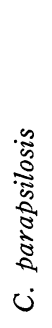 & 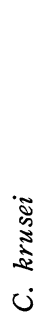 & 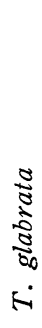 \\
\hline C. tropicalis $\mathrm{I} \mathrm{J}-1017$ & C. tropicalis I AJ 4468 & + & 一 & - & - & - & - & - & - & 一 \\
\hline C. tropicalis I AJ 4468 & C. tropicalis I J-1017 & - & - & - & - & - & - & - & - & - \\
\hline C. tropicalis I J-1017 & C. tropicalis II AJ 4476 & + & + & - & - & - & - & - & - & - \\
\hline C. tropicalis II AJ 4476 & C. tropicalis I J-1017 & - & - & - & - & - & - & - & - & - \\
\hline C. tropicalis I AJ 4468 & C. tropicalis II AJ 4476 & - & - & - & - & - & - & - & - & - \\
\hline C. tropicalis II AJ 4476 & C. tropicalis I AJ 4468 & - & - & - & - & - & - & - & - & - \\
\hline
\end{tabular}

among antisera for C. albicans, C. tropicalis form I and II, and the cells of various species of Candida and Torulopsis (Table 6). The antiserum for $C$. albicans J-1501 absorbed with C. stellatoidea agglutinated cells of C. albicans, C. tropicalis J-1017 (form I), C. tropicalis AJ 4468 (form I), and T. glabrata, but did not agglutinate the cells of $C$. tropicalis AJ 4476 (form II). The same results were obtained in each antiserum for C. tropicalis J-1017, and for C. 
tropicalis AJ 4468 which was absorbed with C. stellatoidea. These results suggest that a strain of $C$. tropicalis AJ 4476 lacks the antigen factor 6 .

When antiserum for C. tropicalis AJ 4476 was absorbed either with $C$. stellatoidea or with $C$. guilliermondii, it demonstrated only a weak antibody related to antibody factors for antigen 6 and 5 , respectively. This result indicates that a strain of $C$. tropicalis AJ 4476 (form II) has a part of antigen 6 as well as antigen 5 which produced only weak antibodies.

A comparative study for antigenic properties of 11 strains of $C$. tropicalis form I and 8 strains of form II was carried out in the same manner as described above (Table 7). In these experiments, all the strains of $C$. tropicalis form I and II were clearly differentiated by the fact that strains of form II lacked antigen 6 and 5 in their agglutinability and in the complete antibodyproducing ability for these two antigens, and antigenic structure of $C$. tropicalis form II can be expressed as $1,2,3,4$, (5), (6), while $1,2,3,4,5,6$ has been proposed for typical strains of $C$. tropicalis, i.e., C. tropicalis form I (15).

\section{Gel diffusion-precipitation test}

Gel diffusion-precipitation reaction of antisera for two forms of C. tropicalis against extracted polysaccharide of these strains and several other Candida species is shown in Figs. 1-3. These polysaccharides contained only D-mannose when they were hydrolyzed. When antiserum for C. tropicalis AJ 4468 (form I) was placed in the central well, an intensive precipitin band was formed against each of extracted mannans of $C$. tropicalis form I and II, and C. guilliermondii placed in the peripheral wells (Fig. 1). In this case, the precipitin band for $C$. tropicalis form I exhibited a spur to the precipitin band for $C$. tropicalis form II. When antiserum for C. tropicalis J-1017 (form I) was placed in the central well, intensive precipitin bands were formed against extracted mannans of $C$. tropicalis form I and $C$. guilliermondii, while precipitin band against mannan of $C$. tropicalis form II was very weak (Fig. 2). When antiserum for $C$. tropicalis form II was used, precipitin bands formed against mannans from the species mentioned above fused with each other, and no spur was observed in this case (Fig. 3). Mannans extracted from C. parapsilosis and C. krusei did not react with the antisera for any form of C. tropicalis.

Proton magnetic resonance spectrum of mannans extracted from two forms of C. tropicalis

The PMR spectra of mannans from two forms of C. tropicalis closely resemble each other (Fig. 4). Both have 4 signals with the same chemical shift in $\mathrm{C}-1-\mathrm{H}$ region. However, it is worthy of note that the relative strength of the fourth signal near $\tau 5.0$ is extremely weak in mannan from C. tropicalis form II than in that from $C$. tropicalis form I. The PMR spectrum of 
Table 6. Antigenic characteristics of

\begin{tabular}{|c|c|c|c|}
\hline Antisera for & Absorbed with & 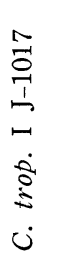 & 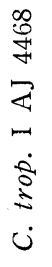 \\
\hline C. albicans J-1501 & $\begin{array}{l}\text { C. tropicalis I J-1017 } \\
\text { C. tropicalis I AJ } 4468 \\
\text { C. tropicalis II AJ } 4476 \\
\text { C. stellatoidea } \\
\text { C. guilliermondii } \\
\text { C. parapsilosis } \\
\text { C. krusei }\end{array}$ & $\begin{array}{l}0 \\
0 \\
0 \\
2 \\
3 \\
3 \\
3\end{array}$ & $\begin{array}{l}0 \\
0 \\
0 \\
2 \\
2 \\
3 \\
3\end{array}$ \\
\hline C. tropicalis I J-1017 & $\begin{array}{l}\text { C. stellatoidea } \\
\text { C. guilliermondii } \\
\text { C. parapsilosis } \\
\text { C. krusei }\end{array}$ & $\begin{array}{l}2 \\
2 \\
2 \\
3\end{array}$ & $\begin{array}{l}2 \\
2 \\
3 \\
3\end{array}$ \\
\hline C. tropicalis I AJ 4468 & $\begin{array}{l}\text { C. stellatoidea } \\
\text { C. guilliermondii } \\
\text { C. parapsilosis } \\
\text { C. krusei }\end{array}$ & $\begin{array}{l}2 \\
2 \\
3 \\
3\end{array}$ & $\begin{array}{l}2 \\
2 \\
3 \\
3\end{array}$ \\
\hline C. tropicalis II AJ 4476 & $\begin{array}{l}\text { C. stellatoidea } \\
\text { C. guilliermondii } \\
\text { C. parapsilosis } \\
\text { C. krusei }\end{array}$ & $\begin{array}{c}0 \\
(1) \\
3 \\
3\end{array}$ & $\begin{array}{c}(1) \\
1 \\
3 \\
3\end{array}$ \\
\hline
\end{tabular}

a Numerals of $1-3$ and those in parentheses indicate degree of positive agglutina-

mannan from $C$. tropicalis form II was found to be closely related to that of C. guilliermondii.

\section{DISCUSSION}

Two forms of $C$. tropicalis can be differentiated on the basis of assimilation of soluble starch. Morphologically, aged colonies of form I are wrinkled with hair, while those of form II are smooth without hair. This difference, however, is not so important in yeast taxonomy since smooth-rough mutation is commonly observed in many species. These two forms show a slight difference in the maximum growth temperature. Namely, most strains of form 
two forms of Candida tropicalis.

\begin{tabular}{|c|c|c|c|c|c|c|c|}
\hline 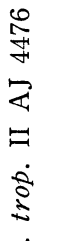 & 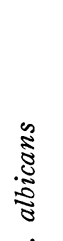 & 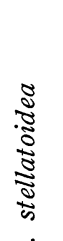 & 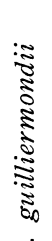 & 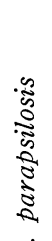 & 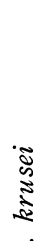 & 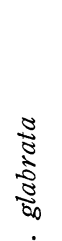 & $\begin{array}{l}\text { Antibody } \\
\text { factors }\end{array}$ \\
\hline ن & $\dot{0}$ & ن & $\dot{0}$ & ن & ن & $\vec{N}$ & \\
\hline 0 & $1^{a}$ & 0 & 0 & 0 & 0 & 0 & 7 \\
\hline 0 & (1) & 0 & 0 & 0 & 0 & 0 & (7) \\
\hline 0 & 2 & 0 & 0 & 2 & 0 & 0 & $7 \ldots$ \\
\hline 0 & 3 & 0 & 0 & 0 & 0 & 1 & $6 \ldots$ \\
\hline 2 & 3 & 1 & 0 & 0 & 0 & 1 & $5 \ldots$ \\
\hline 3 & 3 & 2 & 2 & 0 & 0 & 2 & $4 \ldots$ \\
\hline 3 & 3 & 2 & 3 & 3 & 0 & 2 & $3 . .$. \\
\hline 0 & 2 & 0 & 0 & 0 & 0 & (1) & 6 \\
\hline 0 & 2 & 1 & 0 & 0 & 0 & (1) & $5 \ldots$ \\
\hline 2 & 3 & 1 & 1 & 0 & 0 & 1 & $4 \ldots$ \\
\hline 3 & 3 & 3 & 3 & 1 & 0 & 3 & $3 \ldots$ \\
\hline 1 & 2 & 0 & 0 & 0 & 0 & 1 & 6 \\
\hline 0 & 2 & (1) & 0 & 0 & 0 & 1 & $5 \ldots$ \\
\hline 3 & 3 & 2 & 3 & 0 & 0 & 1 & $4 \ldots$ \\
\hline 3 & 3 & 2 & 3 & 2 & 0 & 3 & $3 \ldots$ \\
\hline (1) & (1) & 0 & 0 & 0 & 0 & (1) & (6) \\
\hline (1) & 1 & (1) & 0 & 0 & 0 & (1) & (5) \\
\hline 3 & 3 & 2 & 3 & 0 & 0 & 0 & $4 \ldots$ \\
\hline 3 & 3 & 3 & 3 & 1 & 0 & 3 & $3 \ldots$ \\
\hline
\end{tabular}

tion.

I could grow above $43^{\circ}$, while all the strains of form II show their maximum growth temperature at $40-41^{\circ}$. Some strains of form I, however, show their maximum growth temperature at $41-42^{\circ}$.

In spite of a scanty difference in taxonomic criteria commonly employed, the two forms of $C$. tropicalis were clearly differentiated by the DNA base composition and serological characteristics. Eight strains of form I of $C$. tropicalis showed the GC content ranging from 34.1 to $34.9 \%$ with a mean value of $34.5 \%$, while 4 strains of form II of C. tropicalis showed the GC content ranging from 36.3 to $36.8 \%$ with a mean value of $36.6 \%$. Therefore, a calculated difference of GC content between the two forms was $2.1 \%$, which is not considered to be due to technical error but must be a true difference. 
Table 7. Slide agglutination experiments for antigenic patterns of

\begin{tabular}{|c|c|c|c|c|c|c|}
\hline \multirow[b]{2}{*}{$\begin{array}{l}\text { Antisera } \\
\text { for }\end{array}$} & \multirow[b]{2}{*}{$\begin{array}{l}\text { Absorbed } \\
\text { with }\end{array}$} & \multicolumn{5}{|r|}{ C. } \\
\hline & & $\begin{array}{l}\stackrel{ }{0} \\
\stackrel{1}{1} \\
\stackrel{1}{\leftrightarrows}\end{array}$ & \begin{tabular}{l}
$\infty$ \\
0 \\
\multirow{J}{*}{} \\
$\&$
\end{tabular} & 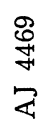 & 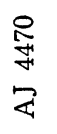 & 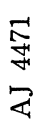 \\
\hline C. albicans $\mathrm{J}-1501$ & C. tropicalis I J-1017 & 0 & 0 & 0 & 0 & 0 \\
\hline "I & C. tropicalis I AJ 4468 & 0 & 0 & 0 & 0 & 0 \\
\hline "I & C. tropicalis II AJ 4476 & 0 & 0 & 0 & 0 & 0 \\
\hline "I & C. stellatoidea & $3^{a}$ & 2 & 3 & 2 & 2 \\
\hline C. tropicalis I J-1017 & C. stellatoidea & 2 & 2 & 2 & 2 & 2 \\
\hline$\prime \prime$ & C. guilliermondii & 2 & 2 & 2 & 2 & 2 \\
\hline C. tropicalis I AJ 4468 & C. stellatoidea $+C$. guilliermondii & 3 & 3 & 3 & 3 & 3 \\
\hline "I & C. guilliermondii & 2 & 2 & 2 & 2 & 2 \\
\hline C. tropicalis II AJ 4476 & C. stellatoidea + C. guilliermondii & $(1)$ & 0 & 0 & (1) & 0 \\
\hline$\prime \prime$ & C. guilliermondii & 1 & 1 & 1 & 1 & 1 \\
\hline
\end{tabular}

a Numerals of 1-3 and those in parentheses indicate degree of positive agglutina-

Serological characteristics also indicated the difference in the two forms. Slide agglutination test (Table 6) and gel diffusion precipitation reaction (Figs. 1-3) suggested that the strains of form I had additional antigens which were not possessed by those of form II, and that some of antigens of form II which are common to form I lack antibody-inducing ability. Diversity in serological characteristics was also reported in C. albicans $(16,17)$. Differing from the case of $C$. tropicalis, however, all the serotypes found in $C$. albicans have the same GC content in DNA, and show almost the same carbon assimilation patterns (18).

A difference was also found in the PMR spectra of alkali-soluble mannans from the two forms. Although PMR spectra of both mannans have 4 signals having the same chemical shift in the $\mathrm{C}-1-\mathrm{H}$ region, the fourth signal near $\tau 5.0$ is very weak in mannan of form II (Fig. 4).

From these considerations, it is concluded that the two forms of C. tropicalis must be closely related to each other but are clearly discriminated. It is considered that these two forms should be dealt with as different species for the sake of convenience. Since the yeast species coinciding with form II of $C$. tropicalis has not yet been reported, this form should be dealt as a new species. The present authors propose to name this yeast Candida subtropicalis since this yeast is assumed to be closely related to $C$. tropicalis. It is interesting that all the strains of $C$. subtropicalis known to date were isolated as strong hydrocarbon-utilizers. The strain AJ 4476 was chosen as the type strain of this species. This strain was deposited in the Fermentation 
isolated strains of two forms of Candida tropicalis.

\begin{tabular}{|c|c|c|c|c|c|c|c|c|c|c|c|c|c|}
\hline \multicolumn{6}{|c|}{ tropicalis form I } & \multicolumn{8}{|c|}{ C. tropicalis form II } \\
\hline$\underset{\underset{H}{N}}{\stackrel{N}{N}}$ & $\begin{array}{l}\stackrel{9}{\leftrightarrows} \\
\underset{H}{4}\end{array}$ & \begin{tabular}{l}
$\infty$ \\
\multirow{7}{*}{}
\end{tabular} & $\begin{array}{l}\infty \\
\stackrel{\infty}{\sharp} \\
\forall\end{array}$ & $\underset{\mathscr{H}}{\stackrel{\sim}{\sharp}}$ & 过 & 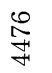 & $\underset{\stackrel{N}{\Im}}{\stackrel{N}{\sharp}}$ & 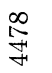 & 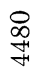 & 令 & $\begin{array}{l}\stackrel{\leftrightarrow}{\$} \\
\underset{+}{+}\end{array}$ & 뇽 & $\begin{array}{l}\infty \\
\infty \\
\qquad 10\end{array}$ \\
\hline$\gtrless$ & Z & 学 & 孛 & Z & Z & 飞 & 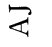 & Z & \& & Z & \& & 学 & 隺 \\
\hline 0 & 0 & 0 & 0 & 0 & 0 & 0 & 0 & 0 & 0 & 0 & 0 & 0 & 0 \\
\hline 0 & 0 & 0 & 0 & 0 & 0 & 0 & 0 & 0 & 0 & 0 & 0 & 0 & 0 \\
\hline 0 & 0 & 0 & 0 & 0 & 0 & 0 & 0 & 0 & 0 & 0 & 0 & 0 & 0 \\
\hline 2 & 2 & 2 & 3 & 2 & 3 & 0 & 0 & 0 & 0 & 0 & 0 & 0 & 0 \\
\hline 2 & 2 & 2 & 2 & 2 & 2 & 0 & 0 & 0 & 0 & 0 & 0 & 0 & 0 \\
\hline 2 & 3 & 3 & 3 & 2 & 2 & 0 & 0 & 0 & 0 & 0 & 0 & 0 & 0 \\
\hline 3 & 3 & 3 & 3 & 3 & 3 & 1 & 1 & 1 & 1 & 1 & 1 & 1 & 1 \\
\hline 2 & 2 & 2 & 2 & 2 & 2 & 1 & (1) & 1 & 1 & 1 & 1 & 1 & 1 \\
\hline 0 & 0 & 0 & 0 & 0 & 0 & (1) & 0 & 0 & (1) & (1) & (1) & 0 & (1) \\
\hline (1) & (1) & (1) & (1) & 1 & 1 & (1) & (1) & (1) & 1 & 1 & (1) & (1) & 1 \\
\hline
\end{tabular}

tion.

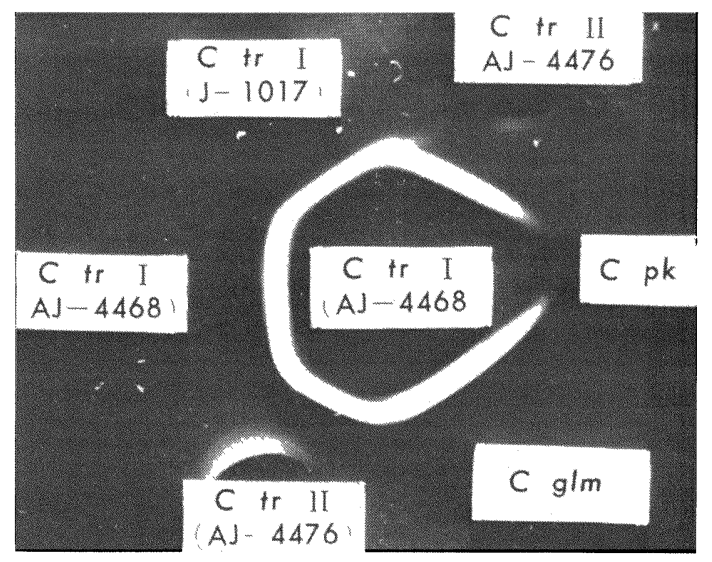

Fig. 1. Serological relationship among mannans of Candida tropicalis and allied species by gel diffusion-precipitation (1).

Center well: Anti-C. tropicalis AJ 4468 serum

Peripheral wells: Mannan solution

C. tr. I: C. tropicalis form I

C. tr. II : C. tropicalis form II

C. glm: C. guilliermondii

C. pk: C. parapsilosis (=C. parakrusei) 


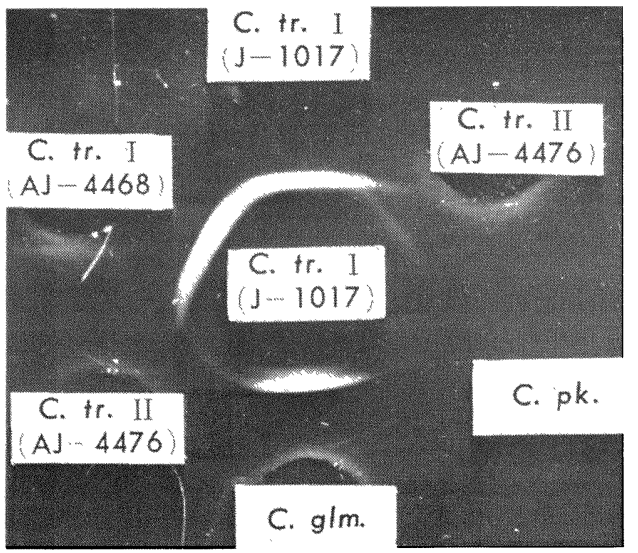

Fig. 2. Serological relationship among mannans of Candida tropicalis and allied species by gel diffusion-precipitation (2).

Center well : Anti-C. tropicalis J-1017 serum

Peripheral wells: Mannan solution

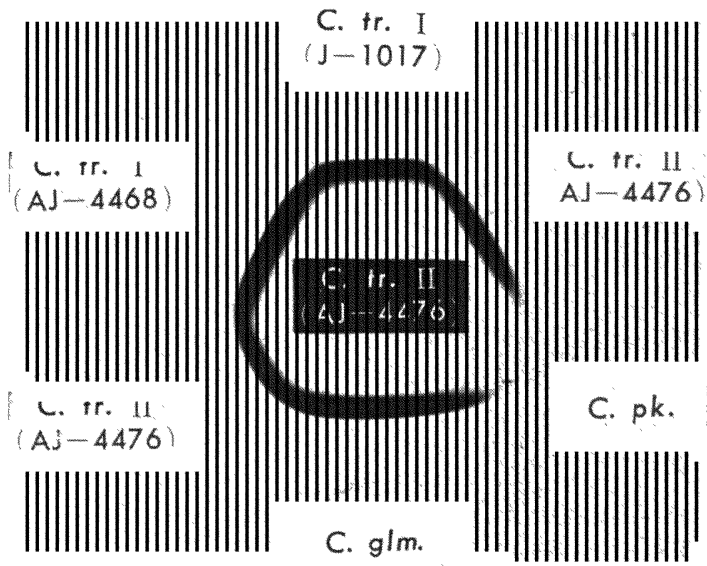

Fig. 3. Serological relationship among mannans of Candida tropicalis and allied species by gel diffusion-precipitation (3).

Center well: Anti-C. tropicalis AJ 4476 serum

Peripheral wells: Mannan solution

Research Institute, Agency of Industrial Science and Technology, Inage, as FERM-P 889. 


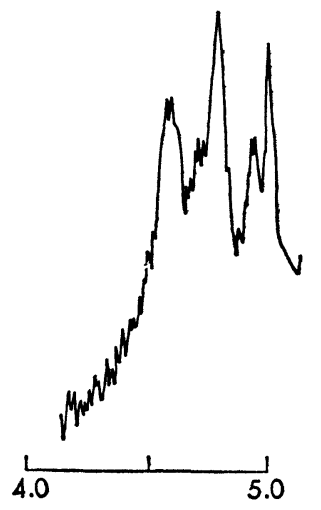

C. tropicalis ( I ) $\mathrm{J}-1017$

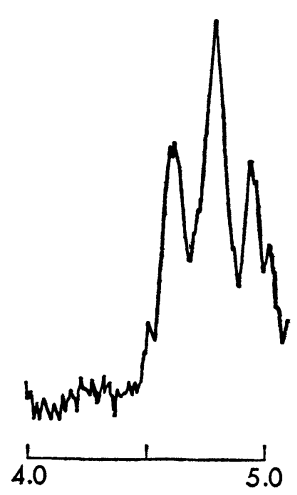

C. tropicalis (II) AJ -4476

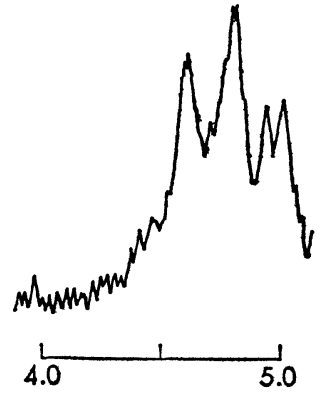

C. tropicalis ( I ) AJ -4468

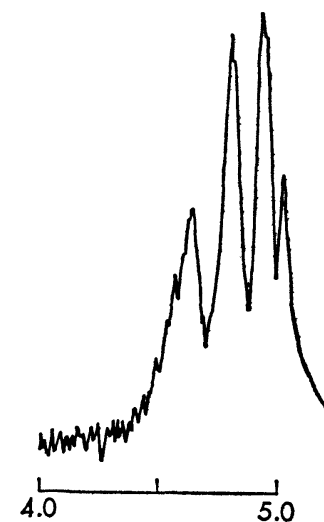

C. guilliermondii $\mathrm{J}-1023$

Fig. 4. Proton magnetic resonance spectra of $\mathrm{C}-1-\mathrm{H}$ region of mannans from Candida tropicalis and Candida guilliermondii.

Numerals indicate $\tau$ values.

\section{DESCRIPTION}

Candida subtropicalis NAKASE, FUKAZAWA et TSUCHIYA sp. nov.

Strain: See Table 1.

In medio liquido cellulae rotundae, subovoideae, ovoideae aut longae, (2.5-9) $\times(3-11-30) \mu$, singulae, binae aut catenatae. Anulus formatur. Cultura in agaro (post unum mensem, $17^{\circ}$ ) flavoalbida, glabra, mollis, margine piloso. Pseudomycelium et mycelium formantur. D-Glucosum, D-galactosum, 
saccharosum et maltosum fermentantur at non lactosum, raffinosum, nec melibiosum. In medio minerali D-glucosum, D-galactosum, saccharosum, maltosum, L-sorbosum (aut lente), cellobiosum (varium), trehalosum, melezitosum, Dxylosum, ethanolum, glycerolum (aut lente), adonitolum, D-mannitolum, Dsorbitolum, $\alpha$-methyl-D-glucosidum, salicinum (varium), potassium gluconatum (varium), calcium 2-ketogluconatum, acidum DL-lacticum (varium), acidum succinicum, et acidum citricum (aut lente) assimilantur at non lactosum, melibiosum, raffinosum, inulinum, amylum, L-arabinosum, D-arabinosum, D-ribosum, L-rhamnosum, erythritolum, dulcitolum, nec inositolum. Nitras kalicus non assimilatur. Arbutinum non finditur. Biotinae necessariae ad crescentiam. Maxima temperatura crescentiar: 40-41.

Growth in YM broth: After 3 days at $25^{\circ}$, cells are round, short oval, oval, or elongate, $(2.5-9) \times(3-11-30) \mu$, and occur singly, in pairs, or in chains. A thin pellicle is formed.

Growth on YM agar: After one month at $17^{\circ}$, the colony is pale yellowish white, smooth, soft, and has a ciliate margin.

Slide culture on potato glucose agar: True and pseudomycelium develop abundantly. Blastospores are round to short oval or oval, and occur singly, in chains, or in clusters.

Formation of ascospores: Not observed.

Fermentation: D-Glucose, D-galactose, saccharose, and maltose (occasionally weak) are fermented. Lactose, raffinose, and melibiose are not fermented.

Assimilation of carbon compounds : D-Glucose, D-galactose, saccharose, maltose, L-sorbose (sometimes latent), cellobiose (variable), trehalose, melezitose, D-xylose, ethanol, glycerol (sometimes latent); adonitol, D-mannitol, D-sorbitol, $\alpha$-methyl-D-glucoside, salicin (variable), potassium gluconate (variable), calcium 2-ketogluconate, DL-lactic acid (variable), succinic acid, and citric acid (occasionally latent) are assimilated. Lactose, melibiose, raffinose, inulin, soluble starch, L-arabinose, D-arabinose, D-ribose, L-rhamnose, erythritol, dulcitol, and inositol are not assimilated.

Utilization of potassium nitrate: Negative.

Splitting of arbutin: Negative.

Splitting of fat: Positive.

Urease: Negative (on Christensen's medium)

Liquefaction of gelatin: Negative.

Formation of starch: Negative.

Requirement of vitamins: Biotin is required at $25^{\circ}$.

Maximum growth temperature: $40-41^{\circ}$.

The authors wish to thank Dr. K. Komagata and Dr. T. Shinoda for their invaluable comments on this work. Many thanks are also due to Dr. H. Akiyama for the determination of PMR spectra, and to Miss S. Miyazawa for technical assistance. 


\section{REFERENCES}

1) J.W. Fell and S.A. Meyer, Mycopathol. Mycol. Appl., 32, 177 (1967).

2) A. Kocková-Kratochvílová, J. Sandúla, A. Vojtkova, M. Pokorna, and V. STUCHLRK, Eolia Microbiol., 12, 327 (1967).

3) N. van Uden and H. Buckley, Genus Candida Berkhout, In The Yeasts, a Taxonomic Study, ed. by J. LodDER, North-Holland Publ. Co., Amsterdam (1970).

4) T. NAKAse, Y. FukAzAWA, and T. TsuchiyA, Shinkin to Shinkinsho, 10, 222 (1969), in Japanese.

5) L.J. Wickerham, Taxonomy of Yeasts, U.S.D.A. Tech. Bull., No. 1029 (1951).

6) J. Lodder and N.J.W. Kreger-van Rij, The Yeasts, a Taxonomic Study, NorthHolland Publ. Co., Amsterdam (1952).

7) K. Komagata and T. Nakase, Shokuhin Eiseigaku Zasshi, 8, 53 (1967), in Japanese.

8) T. NAKase, J. Gen. Appl. Microbiol., 17, 383 (1971).

9) T. NAKAse and K. Komagata, J. Gen. Appl. Microbiol., 14, 345 (1968).

10) J. MARmur and P. Doty, J. Mol. Biol., 5, 109 (1962).

11) K. Yamada and K. Komagata, J. Gen. Appl. Microbiol., 16, 215 (1970).

12) P.A.J. Gorin and J.F.T. Spencer, Can. J. Chem., 46, 2299 (1968).

13) T. Tsuchiya, Y. Fukazawa, S. Hayashi, J. Hayashi, and M. Doi, Jap. J. Microbiol., 1, 125 (1957).

14) Ö. OuchterlonY, Gel-diffusion techniques, In Immunological Methods, ed. by J.F. Ackroyed, Blackwell Scientific Publ., Oxford (1964).

15) T. Tsuchiya, Y. Fukazawa, and S. Kawakita, Mycopathol. Mycol. Appl., 26, 1 (1965).

16) H.F. Hasenclever and W.O. Mitchell, J. Bacteriol., 82, 570 (1961).

17) Y. FukAzAwA, Shinkin to Shinkinsho, 10, 132 (1969), in Japanese.

18) T. Nakase and K. Komagata, J. Gen. Appl. Microbiol., 17, 259 (1971).

19) K. Komagata, T. Nakase, and N. Katsuya, J. Gen. Appl. Microbiol., 10, 323 (1964). 